\title{
What College Students Post About Depression on Facebook and the Support They Perceive: Content Analysis
}

Scottye Cash ${ }^{1}$, MSSW, PhD; Laura Marie Schwab-Reese ${ }^{2}$, MA, PhD; Erin Zipfel ${ }^{1}$, MSW; Megan Wilt ${ }^{3}$, BA; Megan Moreno $^{3}$, MD, MPH, MSED

${ }^{1}$ College of Social Work, The Ohio State University, Columbus, OH, United States

${ }^{2}$ Department of Health \& Kinesiology, Purdue University, West Lafayette, IN, United States

${ }^{3}$ Department of Pediatrics, University of Wisconsin-Madison, Madison, WI, United States

\section{Corresponding Author:}

Scottye Cash, MSSW, PhD

College of Social Work

The Ohio State University

1947 College Rd

Columbus, OH, 43210

United States

Phone: 16142923690

Email: cash.33@osu.edu

\section{Abstract}

Background: College students frequently use social media sites to connect with friends. Increasingly, research suggests college students and other young adults seek mental health-related support on social media, which may present a unique venue for intervention.

Objective: The purpose of this study was to examine college students' perceptions about displaying feelings of depression on Facebook and, in turn, how their social media friends responded.

Methods: A primarily quantitative online survey with open response questions was distributed to students at four US universities. Qualitative responses were analyzed using content analysis.

Results: A total of 34 students provided qualitative responses for analysis, these students were $85.3 \%$ female, mean age 20.2 $(\mathrm{SD}=1.4)$ and $20.6 \% \mathrm{racial} / \mathrm{ethnic}$ minority. Students who reported posting about depression often expressed an emotion or feeling but did not use the word "depression" in the post. Approximately $20 \%$ posted language about a bad day, and $15 \%$ posted a song or music video. Only one person reported posting a statement that directly asked for help. When friends responded to the posts, students generally perceived the responses as supportive or motivating gestures. Nearly $15 \%$ of friends contacted the individual outside of Facebook. One individual received a negative response and no responses suggested that the individual seek help.

Conclusions: This study found that college students who post about depression often do so without directly referencing depression and that friends were generally supportive. However, no participants reported their social network suggested they seek help, which may suggest increasing mental health literacy, for both support seekers and responders, would be an opportunity to improve online mental health-related support.

(JMIR Form Res 2020;4(7):e13650) doi: $\underline{10.2196 / 13650}$

\section{KEYWORDS}

social media; depression; college students; qualitative

\section{Introduction}

Depression is a common health issue among college students [1-4]. Untreated depression may cause a number of adverse outcomes, including substance use, suicidal behaviors, and other psychiatric conditions [5-10]. Obtaining help with depression can be complicated by students' inability to understand their symptoms, denial of symptoms, unwillingness to reach out for formal help, a lack of available mental health resources, and other complications associated with depression severity $[2,3,11]$. Innovative approaches are needed to increase the knowledge about depression and help-seeking resources while also reducing the stigma associated with mental health issues. 
Internet-based or online social networks may be an important avenue for young people to seek and receive support related to mental health and to access mental health resources. In 2018, nearly all young people in the United States used the internet through home broadband or smartphones [12]. Social network site use is nearly as ubiquitous. In 2018, YouTube was used by the greatest percentage of 18- to 24-year-old Americans (94\%), followed by Facebook (80\%), Snapchat (78\%), and Instagram (71\%) [13]. Although social media use has been shown to be associated with increased mental health issues under some circumstances [14-18], a growing body of literature has shown that college students use social network sites, such as Facebook and Twitter, to discuss mental health concerns and seek support [19-22]. Moreno and colleagues [20] found that $25 \%$ of respondents had some evidence of depression symptoms in their Facebook posts, and $2.5 \%$ posted about symptoms that met the criteria for a major depressive episode. The authors also found that individuals who posted about depression were online more often than those who did not [20]. Support-seeking behaviors may be driving this increased use. One study demonstrated that young adults with a mental health diagnosis were more likely to seek support online and to engage in various other social connection-seeking activities than peers without a mental health diagnosis [21]. However, social media engagement may not be entirely positive. In another study of social media use among adolescents with depression diagnosis, participants used social media in ways that were likely to positively (eg, entertainment, humor) and negatively (eg, sharing risky behaviors, cyberbullying) impact their symptoms [22].

Few studies have examined the type of response that students receive from peers when they post about depression symptoms on Facebook. In one study, a positive association was found between depression symptom posts and peer responses, and peer responses were generally positive and supportive [20]. However, in another study, participants perceived depression symptom posts as "drama" and were reluctant to offer help or support [23]. This discrepancy may be due to differences in how individuals with depression perceive social interactions compared with nondepressed peers. One small study found that individuals who posted about depression thought they received less support, but a review of actual social support transactions found that posts about depression symptoms were associated with increased social support from Facebook connections [24].

Despite growing evidence about the objective use of Facebook and other social network sites to share emotions/experiences related to depression, relatively less is known about how young people perceive those experiences [25]. The purpose of this study was to determine how college students perceived their help-seeking posts about depression and the types of responses they received.

\section{Methods}

\section{Design}

Data for this analysis were extracted from a comprehensive mixed method, multisite, cross-sectional study conducted between September and November 2012. The purpose of the overall study was to assess multiple health outcomes among a college student population, including mental health and technology-related behaviors. Data were collected via an online survey with college students from four universities in the United States. The four universities were selected to provide geographic variation and a mix of public and private schools. Of these, three were in the Midwest and one was in the West. All participants in the overall study were invited to respond to all relevant questions, including the qualitative questions reported in this paper. As the Patient Health Questionnaire-9 (PHQ-9) includes questions regarding suicidal thoughts over the past 2 weeks, students were provided a list of Web-based mental health resources as a condition of the institutional review board (IRB) approval. This study was approved by each university's affiliated IRB.

\section{Procedures}

Paper fliers with a link to the online Catalyst WebQ survey (https://itconnect.uw.edu/learn/tools/catalyst-web-tools/webq/) were distributed to 662 college students taking biology, communications, psychology, and nursing classes during the Autumn semester in 2012. These specific classes were selected to be able to reach a diverse set of students, as many were introductory classes required across different majors in order to be able to reach a diverse set of students. Each college class that was included in the study had a general Listserv that the professors used to communicate with students. In all, two to three follow-up emails were sent via the course Listserv to all 662 students who received the flier. Students who accessed the survey were required to complete an informed consent. A US $\$ 5$ Starbucks gift card was given to those who completed the survey. In one class, students who completed the survey received extra credit in addition to the gift card. To complete the survey, students were required to be between the age of 18 and 23 years, and this inclusion criterion was included in recruitment materials. Any respondents outside this age range were excluded from this analysis. The response rate for the overall survey was $43.3 \%(n=287)$. The final sample size for this study was 33 students, which represented $11 \%$ of the total sample.

\section{Sample}

The sample for this study included all participants $(n=33)$ who provided qualitative responses to the survey question on the nature of their and their friends' responses to their Facebook posts and who had completed the questions on the PHQ-9.

A $t$ test was used to determine if there were demographic and mental health differences between this study sample $(n=33)$ and the sample of students who did not complete the open-ended questions $(n=253)$. There was a statistically significant difference $(P=.001)$ in the mean score on PHQ-9 between those who completed the qualitative Facebook questions (mean 9.06, SD 6.43) and those who did not complete those questions (mean 4.92 , SD 4.25). No other statistically significant differences were identified between the full sample and the subset of participants in this study.

\section{Measures}

Demographic data were collected from each participant, including age, race/ethnicity, relationship status, sexual orientation, and year in school. 


\section{Depression}

Depression was measured using the PHQ-9. The PHQ-9 score was based on the instrument guidelines with the following categorization: <4=minimal depression, 5-9=mild depression, 10-14=moderate depression, 15-19=moderately severe depression, and 20-27=severe depression. A total score of 10 or more points was used in this study to indicate at least moderate depression systems, which was consistent with the prior use of the questionnaire [26]. The PHQ-9 was chosen to measure depression in this study because it has been validated in both adolescent and adult populations [27,28].

\section{Qualitative Facebook questions}

Participants were asked to identify if they had ever reached out on Facebook when feeling depressed and if yes, to describe the post(s). Participants were then asked to describe the nature of comments their friends made in response to a post, where they relayed some variation of feelings of depression. A copy of the questions are presented in Multimedia Appendix 1. The qualitative Facebook questions were developed by a study investigator, who based these questions on an internet survey about support-seeking behaviors used by adolescents when they were depressed [29]. Other researchers in the team then conducted an initial review of the Facebook questions for face validity and assessed them for question clarity. Prior to implementing the survey, the questions were also vetted by several college students.

\section{Analyses}

The first purpose of the study was to identify themes in participant perceptions regarding depression-related Facebook posts and their friend's responses. Classic content analysis [30-32] was used to examine responses to the two open-ended questions. Three investigators defined categories a priori (see Table 1). Investigators then participated in three rounds of practice coding. Discrepancies were discussed after each round of coding. An interrater agreement of 0.79 was obtained on a subset of 10 quotes before coding of the full subsample. The remaining data were divided among three coders and an open coding approach was used to categorize the total sample of open-ended responses. As ambiguous or unclear cases emerged, they were discussed and assigned the category agreed up on by all three coders. The final interrater agreement on all 33 statements was 0.90 .

Table 1. Qualitative themes and definitions for participant posts and their friends' responses.

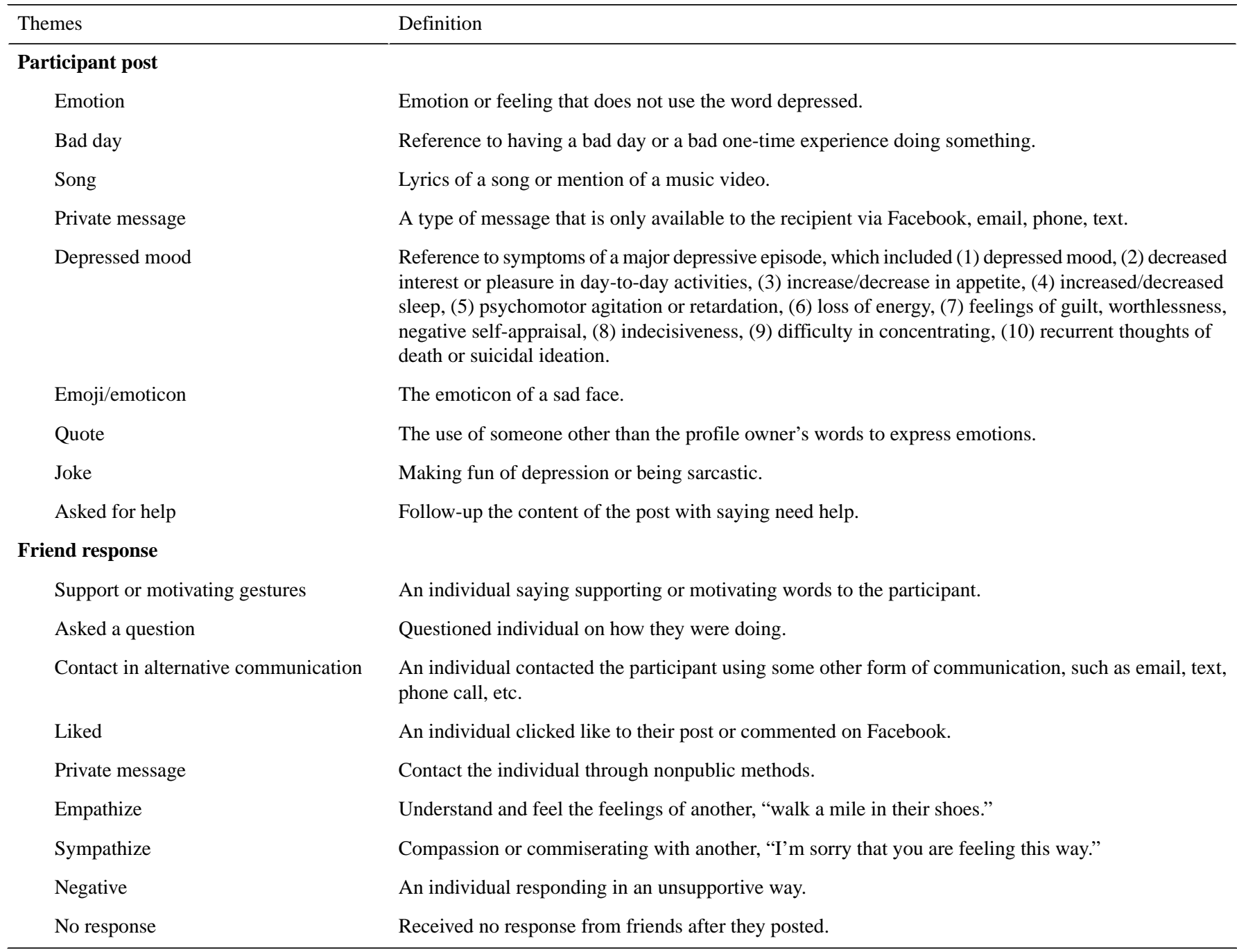


We conducted bivariate analyses to assess if the theme of friend's response differed by the theme(s) of the participant's post. We also conducted bivariate analyses to assess differences between themes of the participant's posts, by depression severity. To test for statistical significance with these analyses, while accounting for the small sample size and cell counts, we used Fisher exact test.

\section{Results}

The mean age of the 33 participants was 20.2 (SD 1.4) years. The majority of participants were female $(n=28,85 \%)$ and Caucasian $(n=26,79 \%)$. Participants were at different stages in their studies, with $24 \%$ freshman $(n=8), 18 \%$ sophomore $(n=6)$, $36 \%$ junior $(n=12)$, and $24 \%$ senior $(n=8)$. Almost half of the participants were single $(\mathrm{n}=16,48.5 \%)$, and only one person identified himself as homosexual.

The mean score on the PHQ-9 was 9.06 (SD 6.43; n=33). Based on the normed scoring criteria, those who scored 10 or more points were considered to be clinically depressed. Of note, $12 \%$ had minimal depression $(\mathrm{n}=5), 33 \%$ had mild depression $(\mathrm{n}=11)$, $27 \%$ had moderate depression $(n=9), 6 \%$ had moderate to severe depression $(n=2)$, and $12 \%$ had severe depression $(n=4)$; three respondents had a score of 0 on the PHQ-9. Question 9 on the PHQ-9 assesses suicidal thoughts in the last 2 weeks. Of these, $33 \%$ indicated suicidal thoughts on several days $(\mathrm{n}=11)$ and $6 \%$, nearly every day $(\mathrm{n}=2)$.

We used a multiple-response analysis, where participants could identify multiple ways in which they had posted about their depression on Facebook. Of these, 24\% $(n=8)$ most commonly reported that they posted their posting about their emotions, and $18 \%(\mathrm{n}=6)$ referenced a bad day (Table 2). A total of four participants (12\%) referenced a specific form of the word depression or an associated symptom. Of the participants, $15 \%$ $(n=5)$ referenced to lyrics of a song or a music video and $6 \%$ $(n=2)$ included quote from a song. Of these, $12 \%(n=4)$ reported that their friends responded via alternative communication approaches or through a private message; $6 \%(n=2)$ included an emoji/emoticon. Only $1 \%$ participant reported directly seeking help.

Table 2. Number and percentage of themes present in participant's posts

\begin{tabular}{|c|c|c|}
\hline Theme & $\mathrm{n}(\%)^{\mathrm{a}}$ & Example quote \\
\hline Emotion & $8(24)$ & "I'm tired of being treated like crap, etc." "I just said I felt so alone." \\
\hline Bad day & $6(18)$ & $\begin{array}{l}\text { "I made a couple of posts over the course of the past year. In one I posted something similar } \\
\text { to 'Oh man, something's gotta give.' Another one I remember saying 'I'm calling all you } \\
\text { angels."” "Terrible day. Things couldn't get any worse." }\end{array}$ \\
\hline Song & $5(15)$ & $\begin{array}{l}\text { "Something with sad music, or a comment on how frustrated or hard life can be." "I posted } \\
\text { a music video that correlated with my mood that day." }\end{array}$ \\
\hline Private message & $4(12)$ & $\begin{array}{l}\text { "I didn't post something about it, I private messaged a friend for some advice." "I did not post } \\
\text { publicly. I talked to my best friend via Facebook messaging. I talked to her about my problems } \\
\text { and what I should do." }\end{array}$ \\
\hline Depressed mood & $4(12)$ & "Depressed sounding post, which led to friends helping." "Just a sad status." \\
\hline Emoji/emoticon & $2(6)$ & "Generic sad faces or 'screw this' posts." "Sad face." \\
\hline Quote & $2(6)$ & "Just posted a quote about being stressed." \\
\hline Joke & $1(3)$ & "I have posted jokingly about particular days being emotionally difficult." \\
\hline Asked for help & $1(3)$ & "If anyone could help me get through a problem." \\
\hline Other & $2(6)$ & $\begin{array}{l}\text { "It's probably one of the hardest things when you wanna help someone but you know you } \\
\text { can't. And you know you should just worry about yourself but you just can't help it." }\end{array}$ \\
\hline
\end{tabular}

${ }^{\mathrm{a}}$ Qualitative responses may have included multiple themes, so the column does not add up to $100 \%$.

The most common perceived response to the participant's Facebook depression post was gestures of support or motivation $(n=13,39 \%$; Table 3$)$. Almost $15 \%$ of the participants $(n=4)$ mentioned that their friends responded via alternative communication approaches or through a private message. A total of four participants (12\%) discussed receiving "likes." One described a negative response to the depression-related display. No participants reported that their friends encouraged them to seek help. 
Table 3. Number and percentage of themes present in friends' responses.

\begin{tabular}{|c|c|c|}
\hline Theme & $\mathrm{n}(\%)^{\mathrm{a}}$ & Example quote \\
\hline $\begin{array}{l}\text { Support or motivating ges- } \\
\text { tures }\end{array}$ & $13(39)$ & $\begin{array}{l}\text { "All positive, sweet, telling me I will get through anything." "All my close friends were } \\
\text { there to encourage me and letting me know that everything will be okay." }\end{array}$ \\
\hline Asked a question & $7(21)$ & $\begin{array}{l}\text { "If they are generic posts friends generally have to ask what is wrong. It is hard to tell } \\
\text { who cares or who's curious this way though." "They ask what's wrong or text, or message } \\
\text { me to talk." }\end{array}$ \\
\hline $\begin{array}{l}\text { Contact in alternative com- } \\
\text { munication }\end{array}$ & $4(12)$ & $\begin{array}{l}\text { "My best friend called me when she got the message and talked to me for a long time." } \\
\text { "She called me immediately." }\end{array}$ \\
\hline Liked & $4(12)$ & "A few people 'liked' it." "People 'liked' the music video." \\
\hline Private message & $4(12)$ & "They make plans to hang with me and take my mind off of it." \\
\hline Empathize & $2(6)$ & $\begin{array}{l}\text { "They would respond most often by agreeing with me and saying that they were having } \\
\text { a hard time as well." }\end{array}$ \\
\hline Sympathize & $1(3)$ & "Tried to make me feel better, 'hang in there,' etc." \\
\hline Negative & $1(3)$ & "Negatively" \\
\hline No response & $1(3)$ & "Usually they don't respond..." \\
\hline
\end{tabular}

${ }^{a}$ Qualitative responses may have included multiple themes, so percentages do not add up to $100 \%$.

We also explored the relationship between individuals' Facebook post and their friends' perceived response. When a person posted about having a "bad day," $83 \%$ of his/her friends responded with support or motivation and $17 \%$ responded with sympathy. When he/she posted a song, song lyrics, music video, $40 \%$ received a response coded as support or motivation, and $60 \%$ "liked" the post. When the person made an emotional post, $62 \%$ received a support/motivation response, $13 \%$ were asked to communicate outside of Facebook, and $25 \%$ asked a question. When the person wrote that he/she had some depression or depression symptoms, half of his/her friends responded with a negative message and the other half used a private message to communicate. Finally, if the person made a joke about being depressed, he/she received an empathetic response. There was a significant relationship $(P<.001)$ between how a person reached out on Facebook and his/her friend's perceived response. We also explored the relationship between the PHQ-9 category and the type of post the person made on Facebook (Table 4). The themes of the participant posts varied by depression severity.

Table 4. Patient Health Questionnaire-9 categories by theme of participant post.

\begin{tabular}{|c|c|c|c|c|c|c|c|c|c|c|}
\hline $\begin{array}{l}\text { Depression } \\
\text { severity }\end{array}$ & $\begin{array}{l}\text { Song, } \mathrm{n} \\
(\%)\end{array}$ & $\begin{array}{l}\text { Private } \\
\text { message, } \mathrm{n} \\
(\%)\end{array}$ & $\begin{array}{l}\text { Depressed } \\
\text { mood, } \mathrm{n} \\
(\%)\end{array}$ & $\begin{array}{l}\text { Help, n } \\
(\%)\end{array}$ & $\begin{array}{l}\text { Emoji, } \mathrm{n} \\
(\%)\end{array}$ & Joke, $\mathrm{n}(\%)$ & $\begin{array}{l}\text { Bad day, } \mathrm{n} \\
(\%)\end{array}$ & $\begin{array}{l}\text { Emotion, } \mathrm{n} \\
(\%)\end{array}$ & $\begin{array}{l}\text { Quote, } \mathrm{n} \\
(\%)\end{array}$ & $\begin{array}{l}\text { Other, } \mathrm{n} \\
(\%)\end{array}$ \\
\hline $\begin{array}{l}\text { Minimal } \\
(\mathrm{n}=5)\end{array}$ & $0(0)$ & $1(20)$ & $1(20)$ & $1(20)$ & $0(0)$ & $0(0)$ & $1(20)$ & $1(20)$ & $0(0)$ & $0(0)$ \\
\hline Mild ( $n=11)$ & $1(9)$ & $2(18)$ & $1(9)$ & $0(0)$ & $1(9)$ & $1(9)$ & $1(9)$ & $2(18)$ & $1(9)$ & $1(9)$ \\
\hline $\begin{array}{l}\text { Moderate } \\
(\mathrm{n}=9)\end{array}$ & $1(11)$ & $0(0)$ & $1(11)$ & $0(0)$ & $1(11)$ & $0(0)$ & $1(11)$ & $44(44)$ & $0(0)$ & $1(11)$ \\
\hline $\begin{array}{l}\text { Moderate to } \\
\text { severe }(n=2)\end{array}$ & $1(50)$ & $0(0)$ & $0(0)$ & $0(0)$ & $0(0)$ & $0(0)$ & $1(50)$ & $0(0)$ & $0(0)$ & $0(0)$ \\
\hline Severe $(n=4)$ & $0(0)$ & $1(25)$ & $0(0)$ & $0(0)$ & $0(0)$ & $0(0)$ & $2(50)$ & $0(0)$ & $1(25)$ & $0(0)$ \\
\hline
\end{tabular}

\section{Discussion}

\section{Overview}

The purpose of this study was to determine how college students perceived their help-seeking posts about depression and the types of responses received. In our sample, no participants reported using specific indicators of depression symptoms, as defined in the Diagnostic and Statistical Manual of Mental Disorders, Fourth Edition (DSM-IV; eg, guilt/worthlessness, hopeless, depressed mood) [33], which is contrary to the findings of two studies on Facebook posts by depressed individuals that found that some individuals used a language consistent with diagnosable depression symptoms [20,34]. Since our study focused on how individuals perceived their posts, this difference between our studies and the other studies suggests that participants in our study had altered perceptions of the content of and responses to their posts, which is consistent with some prior research on online support seeking [24]. In one prior study, more severe depression symptoms were associated with significantly reduced perceptions of Facebook-related support, despite increased levels of support found in the review of the text of the interactions [24]. A larger body of research has demonstrated a negative bias in how individuals with depression perceive social support and other social perceptions in offline 
interactions [35-37]. Alternatively, social desirability bias may account for the difference between participants' perceptions and review of social media posts in prior studies [20,24,38]. Students may not report using specific depression symptoms due to concerns about social stigma. However, it is unclear why participants in this study would report posting about reaching out on Facebook regarding depression and then withhold that they used depression-specific language.

In addition to triangulating prior studies of Facebook-related mental health support, our study has several implications. In 2017, Facebook implemented a new mechanism for concerned friends and family to provide support for individuals who may be experiencing suicidal thoughts [39]. After a report is made, Facebook will send a message indicating someone expressed concern and will provide a list of resources (eg, suicide and crisis hotlines). Facebook also changed the "Like" function, so that individuals can indicate their reactions (eg, "Like," "Happy," "Wow," "Sad," and "Angry"), rather than simply "liking" a post. This change may alter how participants perceive support, as approximately $12 \%$ of participants reported friends provided support by liking posts. With this increased specificity, friends may choose a reaction, rather than posting a text response. Additional research is necessary to determine how these changes impact the objective support given and perceptions of support received.

Increasing mental health literacy may be another way to improve how friends provide support and individuals request/receive mental health-related support. Increasing mental health literacy has been shown to have a positive effect on reducing mental health stigma and may encourage friends to respond to depressive posts in more helpful ways [40-42]. In addition, Armstrong and Young [40] found that college students in their study preferred that mental health information be delivered via the internet, public service announcements, and the media. Providing health education and positive social support through social media or other online platforms may be one approach to support individuals experiencing depression.

\section{Limitations}

This study was limited by several factors. First, the study was cross-sectional and used a convenience sample. The sample size was small $(n=33)$, which also limits the generalizability of the findings. Thus, the understanding of an individual's perceptions of support seeking and receiving may not generalize to all Facebook users, but are more likely to be generalizable to individuals with depression who have posted about or sought support related to depression, particularly when triangulated with findings from other research studies. In addition, the individuals who responded to the open-ended question about depression-related posts and were thus included in this analysis had higher depression scores than other individuals in the overall multisite study. Thus, perceptions of online support seeking and receipt are likely most generalizable to an individual with more significant depression symptoms. Finally, interactions on Facebook may not be generalizable to other social media platforms. Some young people are likely to disclose sensitive information on social media platforms other than Facebook, due to privacy concerns and concerns about parental presence on Facebook [26,43].

\section{Conclusions}

This study explored how individuals perceived support seeking and their perceptions of the responses. The findings, when combined with those of prior studies, indicate that individuals may perceive their depression-related posts and the related responses differently from how others perceive them. As such, there may be a need to increase mental health literacy to help individuals, including both support seekers and support providers, communicate about mental health. Since stigma is often related to a lack of mental health literacy, enhancing mental health literacy may be an approach to reduce mental health stigma and increase support to individuals with depression symptoms.

\section{Conflicts of Interest}

None declared.

\section{Multimedia Appendix 1}

Study questions about depression posts on Facebook.

[DOCX File, 22 KB-Multimedia Appendix 1]

\section{References}

1. Gallagher RP. National Survey of Counseling Center Directors, 2006 (Monograph Series No. 8P). Alexandria: International Association of Counseling Services, Inc.; 2007.

2. American College Health Association. American College Health Association: National College Health Assessment II: Reference Group Data Report Fall 2008. Baltimore, MD: American College Health Association; 2009.

3. Zivin K, Eisenberg D, Gollust SE, Golberstein E. Persistence of mental health problems and needs in a college student population. J Affect Disord 2009;117(3):180-185 [FREE Full text] [doi: 10.1016/j.jad.2009.01.001] [Medline: 19178949]

4. Hunt J, Eisenberg D. Mental health problems and help-seeking behavior among college students. J Adolesc Health 2010;46(1):3-10 [FREE Full text] [doi: 10.1016/j.jadohealth.2009.08.008] [Medline: 20123251]

5. Kessler RC, Foster CL, Saunders WB, Stang PE. Social consequences of psychiatric disorders, I: educational attainment. Am J Psychiatry 1995;152(7):1026-1032 [FREE Full text] [doi: 10.1176/ajp.152.7.1026] [Medline: 7793438] 
6. Bramesfeld A, Platt L, Schwartz FW. Possibilities for intervention in adolescents' and young adults' depression from a public health perspective. Health Policy 2006;79(2-3):121-131 [FREE Full text] [doi: 10.1016/j.healthpol.2005.11.012] [Medline: $\underline{16414145]}$

7. Deas D, Brown ES. Adolescent substance abuse and psychiatric comorbidities. J Clin Psychiatry 2006;67(7):18-23 [FREE Full text] [doi: 10.4088/jcp.0706e02] [Medline: 17107227]

8. Rao U. Links between depression and substance abuse in adolescents: neurobiological mechanisms. Am J Prev Med 2006;31(6):S161-S174 [FREE Full text] [doi: 10.1016/j.amepre.2006.07.002] [Medline: 17175411]

9. Garlow SJ, Rosenberg J, Moore JD, Haas AP, Koestner B, Hendin H, et al. Depression, desperation, and suicidal ideation in college students: results from the American Foundation for Suicide Prevention College Screening Project at Emory University. Depress Anxiety 2008;25(6):482-488 [FREE Full text] [doi: 10.1002/da.20321] [Medline: 17559087]

10. Rao U, Chen LA. Characteristics, correlates, and outcomes of childhood and adolescent depressive disorders. Dialogues Clin Neurosci 2009;11(1):45-62. [Medline: 19432387]

11. Eisenberg D, Golberstein E, Gollust E. Help-seeking and access to mental health care in a university student population. Med Care 2007;45(7):594-601 [FREE Full text] [doi: 10.1097/MLR.0b013e31803bb4c1] [Medline: 17571007]

12. Pew Research Center. 2018. Internet/Broadband Fact Sheet URL: http://www.pewinternet.org/fact-sheet/internet-broadband/ [WebCite Cache ID 6oNny1FMh]

13. Pew Research Center. 2018. Social Media Use in 2018 URL: http://www.pewinternet.org/2018/03/01/ social-media-use-in-2018/[WebCite Cache ID 6ykw0G0Gc]

14. Zhang R. The stress-buffering effect of self-disclosure on Facebook: an examination of stressful life events, social support, and mental health among college students. Comput Hum Behav 2017;75:527-537 [FREE Full text] [doi: 10.1016/j.chb.2017.05.043]

15. Shensa A, Sidani JE, Escobar-Viera CG, Chu KH, Bowman ND, Knight JM, et al. Real-life closeness of social media contacts and depressive symptoms among university students. J Am Coll Health 2018;66(8):747-753 [FREE Full text] [doi: 10.1080/07448481.2018.1440575] [Medline: 29452042]

16. Saunders JF, Eaton AA. Snaps, selfies, and shares: how three popular social media platforms contribute to the sociocultural model of disordered eating among young women. Cyberpsycho Behav Soc Netw 2018;21(6):343-354 [FREE Full text] [doi: 10.1089/cyber.2017.0713] [Medline: 29883209]

17. Vogel EA, Rose JP, Okdie BM, Eckles K, Franz B. Who compares and despairs? The effect of social comparison orientation on social media use and its outcomes. Pers Individ Differ 2015;86:249-256 [FREE Full text] [doi: 10.1016/j.paid.2015.06.026]

18. Frison E, Eggermont S. Exploring the relationships between different types of Facebook use, perceived online social support, and adolescents' depressed mood. Soc Sci Comput Rev 2015;34(2):153-171 [FREE Full text] [doi: $10.1177 / 0894439314567449]$

19. Murrieta J, Frye CC, Sun L, Ly LG, Cochancela CS, Eikey EV. Depression: findings from a literature review of 10 years of social media and depression research. In: Chowdhury G, McLeod J, Gillet V, Willett P, editors. Transforming Digital Worlds. iConference 2018. Lecture Notes in Computer Science. Cham: Springer; 2018:47-56.

20. Moreno MA, Jelenchick LA, Egan KG, Cox E, Young H, Gannon KE, et al. Feeling bad on Facebook: depression disclosures by college students on a social networking site. Depress Anxiety 2011;28(6):447-455 [FREE Full text] [doi: 10.1002/da.20805] [Medline: 21400639]

21. Gowen K, Deschaine M, Gruttadara D, Markey D. Young adults with mental health conditions and social networking websites: seeking tools to build community. Psychiatr Rehabil J 2012;35(3):245-250 [FREE Full text] [doi:

10.2975/35.3.2012.245.250] [Medline: 22246123]

22. Radovic A, Gmelin T, Stein BD, Miller E. Depressed adolescents' positive and negative use of social media. J Adolesc 2017;55:5-15 [FREE Full text] [doi: 10.1016/j.adolescence.2016.12.002] [Medline: 27997851]

23. Egan KG, Koff RN, Moreno MA. College students' responses to mental health status updates on Facebook. Issues Ment Health Nurs 2013;34(1):46-51 [FREE Full text] [doi: 10.3109/01612840.2012.718044] [Medline: 23301569]

24. Park J, Lee DS, Shablack H, Verduyn P, Deldin P, Ybarra O, et al. When perceptions defy reality: the relationships between depression and actual and perceived Facebook social support. J Affect Disord 2016;200:37-44 [FREE Full text] [doi: 10.1016/j.jad.2016.01.048] [Medline: 27126138]

25. Cavazos-Rehg PA, Krauss MJ, Sowles S, Connolly S, Rosas C, Bharadwaj M, et al. A content analysis of depression-related tweets. Comput Human Behav 2016;54:351-357 [FREE Full text] [doi: 10.1016/j.chb.2015.08.023] [Medline: 26392678]

26. Kroenke K, Spitzer RL, Williams JB. The PHQ-9: validity of a brief depression severity measure. J Gen Intern Med 2001;16(9):606-613 [FREE Full text] [doi: 10.1046/j.1525-1497.2001.016009606.x] [Medline: 11556941]

27. Richardson LP, McCauley E, Grossman DC, McCarty CA, Richards J, Russo JE, et al. Evaluation of the patient health questionnaire-9 item for detecting major depression among adolescents. Pediatrics 2010;126(6):1117-1123 [FREE Full text] [doi: 10.1542/peds.2010-0852] [Medline: 21041282]

28. Allgaier AK, Pietsch K, Frühe B, Sigl-Glöckner J, Schulte-Körne G. Screening for depression in adolescents: validity of the patient health questionnaire in pediatric care. Depress Anxiety 2012;29(10):906-913 [FREE Full text] [doi:

10.1002/da.21971] [Medline: 22753313] 
29. Cash SJ, Bridge J. Meeting them where they are: an exploration of technology use and help-seeking behaviors among adolescents and young adults. 2012 Presented at: Poster presented at: 59th Annual Meeting of the American Academy of Child \& Adolescent Psychiatry; Oct 25, 2012; San Francisco, CA.

30. Krippendorf K. Content Analysis: An Introduction to its Methodology, 2nd edition.th edition. Thousand Oaks, CA: Sage; 2004. ISBN: 978-0761915454.

31. Miles M, Huberman M. Qualitative Data Analysis: An Expanded Sourcebook. Thousand Oaks, CA: Sage; 1994. ISBN: 978-0803955400.

32. Weber RP. Basic Content Analysis, 2nd editionth edition. Thousand Oaks, CA: Sage; 1990.

33. American Psychiatric Association. Diagnostic and Statistical Manual of Mental Disorders., 4th edition. Text Revisionth edition. Washington, DC: American Psychiatric Association; 2000.

34. Moreno MA, Jelenchick LA, Kota R. Exploring depression symptom references on Facebook among college freshman: a mixed methods approach. Open J Depress 2013;2(3):35-41 [FREE Full text] [doi: 10.4236/ojd.2013.23008]

35. Holahan CJ, Moos RH, Holahan CK, Cronkite RC, Randall PK. Unipolar depression, life context vulnerabilities, and drinking to cope. J Consult Clin Psychol 2004;72(2):269-275 [FREE Full text] [doi: 10.1037/0022-006X.72.2.269] [Medline: $\underline{15065960]}$

36. Rookm KS. The negative side of social interaction: impact on psychological well-being. J Pers Soc Psychol 1984;46(5):1097-1108 [FREE Full text] [doi: 10.1037/0022-3514.46.5.1097]

37. Davila J, Hershenberg R, Feinstein JA, Gorman K, Bhatia V, Starr LR. Frequency and quality of social networking among young adults: associations with depressive symptoms, rumination, and corumination. Psychol Pop Media Cult 2012;1(2):72-86 [FREE Full text] [doi: 10.1037/a0027512] [Medline: 24490122]

38. Krumpal I. Determinants of social desirability bias in sensitive surveys: a literature review. Qual Quant 2013;47(4):2025-2047 [FREE Full text] [doi: 10.1007/s11135-011-9640-9]

39. Facebook. 2019. Report Suicidal Content URL: https://www.facebook.com/help/contact/305410456169423

40. Armstrong LL, Young K. Mind the gap: person-centred delivery of mental health information to post-secondary students. Psychosoc Interven 2015;24(2):83-87 [FREE Full text] [doi: 10.1016/j.psi.2015.05.002]

41. Canadian Alliance on Mental Illness and Mental Health. 2007 . Mental Health Literacy in Canada: Phase One Draft Report Mental Health Literacy Project URL: http://camimh.ca/wp-content/uploads/2012/04/

Mental-Health-Literacy___Full-Final-Report_EN.pdf

42. Keys S, Cash S. Reachout.com report to California Mental Health Association. San Francisco, CA; 2012.

43. Mullen C, Hamilton NF. Adolescents' response to parental Facebook friend requests: he comparative influence of privacy management, parent-child relational quality, attitude and peer influence. Comput Human Behav 2016;60:165-172 [FREE Full text] [doi: 10.1016/j.chb.2016.02.026]

\section{Abbreviations \\ IRB: institutional review board \\ PHQ-9: Patient Health Questionnaire-9}

Edited by A Tsanas; submitted 07.02.19; peer-reviewed by J Sidani, K Kaipainen, A Benetoli, S Pollak; comments to author 26.03.19; revised version received 24.06.19; accepted 18.11.19; published 17.07.20

Please cite as:

Cash S, Schwab-Reese LM, Zipfel E, Wilt M, Moreno M

What College Students Post About Depression on Facebook and the Support They Perceive: Content Analysis

JMIR Form Res 2020;4(7):e13650

URL: https://formative.jmir.org/2020/7/e13650

doi: $\underline{10.2196 / 13650}$

PMID: 32706687

(CScottye Cash, Laura Marie Schwab-Reese, Erin Zipfel, Megan Wilt, Megan Moreno. Originally published in JMIR Formative Research (http://formative.jmir.org), 17.07.2020. This is an open-access article distributed under the terms of the Creative Commons Attribution License (https://creativecommons.org/licenses/by/4.0/), which permits unrestricted use, distribution, and reproduction in any medium, provided the original work, first published in JMIR Formative Research, is properly cited. The complete bibliographic information, a link to the original publication on http://formative.jmir.org, as well as this copyright and license information must be included. 